\title{
Home Health Care Services: A Look At Audit Opinion Announcements And The Contagion Or Competitive Effect On Rival Firms
}

R. Stephen Elliott, (E-mail: elliott@nsula.edu), Northwestern State University Mark Schaub, (E-mail: schaubm@nsula.edu), Northwestern State University

\begin{abstract}
With the aging of the American population and the increase in demand for health care services, we can expect an increase in investment activity in the health care market. This study focuses on whether intra-industry information transfers from going-concern audit opinion announcements create contagion or competitive stock price reactions in rival home health care firms. Data are derived from a sample of firms traded on the NASDAQ, the New York Stock Exchange, or the American Stock Exchange. Average standardized abnormal returns for each firm are computed during an 8-year period. The findings suggest a dominating competitive effect for rival home health care and miscellaneous home service firms significant at the .05 level.
\end{abstract}

\section{Introduction}

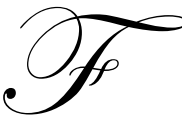

rom 1993 to 1999 U.S. health care expenditures declined as a share of national income for the longest time since the Great Depression. However, since 1999, health care costs have been growing at a rate faster than the overall economy. Research suggests that health care costs are likely to continue growing faster than national income into the foreseeable future (Glied, Spring, 2003). With the aging of the American population and the increase in demand for health care services, we can expect an increase in investment activity in the health care market.

This study focuses on whether intra-industry information transfers from going-concern audit opinion announcements create contagion or competitive stock price reactions in rival home health care firms. The "contagion effect" occurs when the rival firms' stock price reactions tend to be in the same direction as the announcing firm's price reaction. The market interprets the new information as an industry-wide problem. On the other hand, when the rival firms' stock price reaction is in the opposite direction, this is known as the "competitive effect". This occurs when the unfavorable news is perceived to be specific to the announcing firm and therefore creates a new competitive position for the rivals of the announcing firm. Wealth is transferred by stock price change from the troubled firm to its competitors.

From the investor's point of view the question is whether a publicly announced going-concern audit opinion from one firm significantly impacts the stock price of rival firms and in what direction.

Going-concern opinions are issued when there is doubt whether a firm may remain solvent during the next operating period. When going concern opinions are issued, the new negative information released to the public typically results in lower stock prices for the announcing firm. Several studies have examined the information content of audit opinions to determine their relationship to stock price changes and their usefulness as a tool for the proper timing of buying and selling securities. 
Studies by Chow and Rice (1982), Elliott, (1982), and Dodd et al.(1984), found little evidence of a significant abnormal return at the filling date of the $10-\mathrm{K}$ or annual report when statements included a qualified audit opinion. Intuitively, this is expected. Stock prices have already adjusted to the new information as it is announced through the financial media and by leakage. According to the strong form of the efficient market hypothesis, stock prices reflect all new information.

Dopuch et al. (1986), however, found that firms receiving "subject to" qualified audit opinions suffered significant negative abnormal stock price reactions coinciding with the public announcement of the auditor's findings. Dopuch's research differs from other studies in that it focuses on returns of firms when the "subject to" audit opinion is first publicly announced in the media. Jones (1996) found that going-concern opinions contain new information that is subsequently incorporated into the firm's equity valuation.

Related intra-industry information transfer studies by Aharony and Swary (1983) and Gay, Timme, and Yung (1991) found evidence of the contagion effect in the banking industry as a result of bank failures. Laux, Starks, and Yoon (1998) found that rivals of firms announcing large revisions in dividends experience statistically insignificant stock price reactions. Sun and Tang (1998) discovered that downsizing announcements by one firm causes a significant stock price reaction by rival firms at the 0.1 level suggesting that the contagion effect is dominant over the competition effect.

Other informational transfer studies have included bankruptcy and earnings announcements. Lang and Stulz (1992), and Cheng and McDonald (1996), Smirlock and Kaufold (1987), Jacklin and Bhattacharya (1988) addressed the effects of bankruptcy announcements on industry rivals. Firth (1976), Foster (1981), Bannister (1994), and Clinch and Sinclair (1987) examined the informational transfers associated with earning releases. These informational transfer studies provide a theoretical basis for this research, which deals with negative information from "going-concern" audit opinion announcements.

\section{The Problem}

The problem of this paper is to determine whether going-concern audit opinions of announcing firms significantly affect returns of rival home health care firms and to determine the direction of stock price changes. If the audit opinion announcement is followed by a significant stock price reaction by rival firms as well as the announcing firm, this will provide additional evidence that audit opinions may be a useful tool for home health care investors as they buy and sell securities.

\section{Data}

The survey includes only home health care service firms and miscellaneous home and allied services firms found under the SIC 8080 and SIC 8090 classification, respectively, reported by Lexis Nexis in the Business Wire and The Wall Street Journal Index. Only those firms traded on the NASDAQ, the New York Stock Exchange, or the American Stock Exchange are included. Daily financial data are obtained from the CRSP database. The study spans an 8-year period from January 1, 1989 to December 31, 1996. This time period is selected because of the new audit opinion change, which started in 1988, and the general stability and growth of the economy during the 8-year period. A total of 2 announcing firm and 35 rival firms are included in the sample. The sample represents 1 announcing firm and 18 rival firms from SIC 8080 and 1 announcing firm and 17 rival firms from SIC 8090.

\section{Methodology}

To determine the announcement effects of going concern opinions on rival firms, abnormal returns are calculated for each firm. Abnormal returns are the difference between the stock's actual return and its expected return as estimated by the single index model. The single index model is commonly used in event studies dealing with announcement effects. The model is: 
$\mathrm{AR}_{\mathrm{it}}=\mathrm{R}_{\mathrm{it}}-\left(\mathrm{a}_{\mathrm{i}}+B_{\mathrm{i}} \mathrm{R}_{\mathrm{mt}}\right)$

where:

$\mathrm{AR}_{\mathrm{it}}=$ the abnormal return on stock $\mathrm{i}$ for day $\mathrm{t}$,

$\mathrm{R}_{\mathrm{it}}=$ the return on stock $\mathrm{i}$ for day $\mathrm{t}$,

$\mathrm{R}_{\mathrm{mt}}=$ the return on the CRSP equally-weighted market portfolio for day $\mathrm{t}$, and

$\mathrm{a}_{\mathrm{i}}, B_{\mathrm{i}}=$ the OLS estimates of the market model parameters.

Abnormal returns are computed for each firm during an event window represented by one day before the announcement, the day of the announcement, and one day after the announcement date. In addition, abnormal returns of the 10 days before and after the announcement date are statistically tested over a one-year period (250 trading days) to determine whether there is leakage or slow dissemination of information.

The abnormal returns are statistically tested to determine whether they are significantly different from zero. To correct for heteroskedasticity, the test statistics are based on standardized abnormal returns derived from the following equation:

$\mathrm{SAR}_{\mathrm{it}}=\mathrm{AR}_{\mathrm{it}} / \mathrm{S}_{\mathrm{ie}}$

where:

$\mathrm{SAR}_{\mathrm{it}}=$ the standardized abnormal return of security $\mathrm{i}$ on day $\mathrm{t}$,

$\mathrm{AR}_{\mathrm{it}}=$ the abnormal return computed for security $\mathrm{i}$ on day $\mathrm{t}$, and

$\mathrm{S}_{\mathrm{ie}}=$ the standard error of security $\mathrm{i}$ over the estimation period.

The standardized average abnormal returns of the industry rival firms are computed from the following equation to determine whether these returns are significantly different from zero.

$\operatorname{ASAR}_{\mathrm{t}}=1 / \mathrm{N} \sum_{\mathrm{i}=1}^{\mathrm{N}} \mathrm{SAR}_{\mathrm{it}}$

where:

$\mathrm{ASAR}_{\mathrm{t}}=$ the average standardized abnormal return on day $\mathrm{t}$,

$\mathrm{N} \quad=$ the number of firms announcing or non-announcing, and

$\mathrm{SAR}_{\mathrm{it}}=$ the standardized abnormal returns computed for firm $\mathrm{i}$ on day $\mathrm{t}$.

The average standardized abnormal return is computed for each firm during an event window represented by 10 days before and after the announcement date and one day before the announcement, the day of the announcement, and one day after the announcement date. Abnormal returns are statistically tested over a one-year period ( 250 trading days) to determine whether there is leakage or slow dissemination of information. The average standardized abnormal returns are tested with a two-tailed t-test at the $.10, .05$, and .01 significance levels. The findings of Dopuch et al. (1986) and Jones (1996) suggest that abnormal returns for the announcing firms are expected to be negative and significant indicating an adverse stock price reaction to the bad news. Industry rival 
firms may have average abnormal returns that are positive or negative depending on whether a contagion or competitive effect exists.

\section{Findings}

Findings suggest a dominating competitive effect for rival home health care and miscellaneous home service firms. The home health care industry is characterized as an oligopoly market with relatively few firms. The competitive effect tends to predominate as investors sell shares in the financially weak firm and buy shares in perceived stronger competing firms. In Table 1, home health care service firms (SIC 8080) show a 5.18 percent average abnormal return for rival firms during the event window of one day before and after the announcement of the going-concern opinion. This is significant at the .01 level with a t-value of 5.152. Miscellaneous home and allied services firms (SIC 8090) in Table 2 shows average abnormal returns of 2.77 percent during the event window. With a t-value of 2.131 , this is significant at the .05 level.

\section{Conclusions and Implications}

The findings suggest that going-concern audit opinions of one firm influence stock prices of other firms in the industry. Average abnormal returns to rival firms are positive and significant at the .01 and .05 level for the SIC 8080 and SIC 8090 firms, respectively. This research supports similar findings of Lang and Stulz (1992) who found that rivals firms in an oligopolistic industry show a positive reaction to bankruptcy announcements. Implications of this study tend to support the efficient market hypothesis in that stock prices rapidly reflect all new information available. These findings are important to institutional and private investors of home health care securities as they seek to maximize stock returns as audit information is announced. Stock prices are generally expected to increase in rival health care firms as going-concern audit opinions are announced by a competing firm.

Table 1: Average Abnormal Returns to Rivals of Firms Announcing a Going Concern Opinion: Sic 8080

\begin{tabular}{|c|c|c|c|c|}
\hline $\begin{array}{l}\text { Day Relative To } \\
\text { Announcement Date: }\end{array}$ & $\begin{array}{c}\text { Average Abnormal Return: } \\
(\%)\end{array}$ & T-value: & & Number of Observations: \\
\hline-10 & 0.1661 & 0.454 & & 18 \\
\hline-9 & 0.7746 & 0.761 & & 18 \\
\hline-8 & -1.1298 & -0.611 & & 18 \\
\hline-7 & -0.6574 & -0.748 & & 18 \\
\hline-6 & -2.2911 & -1.471 & & 18 \\
\hline-5 & -0.2027 & -0.667 & & 18 \\
\hline-4 & 1.7434 & 1.766 & & 18 \\
\hline-3 & -3.4785 & -2.664 & $* *$ & 18 \\
\hline-2 & -1.1848 & -0.465 & & 18 \\
\hline-1 & 0.8604 & 0.561 & & 18 \\
\hline 0 & 3.0005 & 2.788 & $* *$ & 18 \\
\hline+1 & 1.3206 & 1.803 & $*$ & 18 \\
\hline$(-1,1)$ & 5.1814 & 5.152 & $* * *$ & 18 \\
\hline+2 & -0.8908 & -0.418 & & 18 \\
\hline+3 & 1.7868 & 1.554 & & 18 \\
\hline+4 & 0.4578 & 0.351 & & 18 \\
\hline+5 & -0.0304 & 0.713 & & 18 \\
\hline+6 & 1.6455 & 1.866 & $*$ & 18 \\
\hline+7 & 1.8491 & 1.401 & & 18 \\
\hline+8 & -3.8252 & -3.203 & $* * *$ & 18 \\
\hline+9 & 2.1379 & 1.723 & & 18 \\
\hline+10 & -1.5072 & -1.523 & & 18 \\
\hline
\end{tabular}

*** Significant at the $1 \%$ level under a two-tailed test.

** Significant at the 5\% level under a two-tailed test.

* Significant at the $10 \%$ level under a two-tailed test. 
Table 2: Average Abnormal Returns To Rivals Of Firms Announcing A Going Concern Opinion: Sic 8090

\begin{tabular}{c|c|c|c}
\hline $\begin{array}{c}\text { Day Relative To } \\
\text { Announcement Date: }\end{array}$ & $\begin{array}{c}\text { Average Abnormal Return: } \\
(\%)\end{array}$ & T-value: & Number of Observations: \\
\hline-10 & -1.9064 & -0.775 & 17 \\
-9 & 3.1941 & 1.162 & 17 \\
-8 & 0.9834 & 1.594 & 17 \\
-7 & -1.8701 & -1.725 & 17 \\
-6 & -0.1914 & -0.192 & 17 \\
-5 & 3.0519 & 1.403 & 17 \\
-4 & -2.6141 & -1.025 & 17 \\
-3 & -0.2619 & -0.412 & 17 \\
-2 & 1.5825 & 1.367 & 17 \\
\hline-1 & 0.9941 & 1.275 & 17 \\
0 & 2.8386 & 0.561 & 17 \\
+1 & -1.0615 & 0.293 & 17 \\
\hline$-1,1)$ & 2.7711 & 2.131 & 17 \\
+2 & 0.0789 & 0.293 & 17 \\
+3 & -1.7491 & -2.434 & 17 \\
+4 & 0.3609 & -0.162 & 17 \\
+5 & 2.5867 & 0.361 & $* *$ \\
+6 & -2.8203 & -1.005 & 17 \\
+7 & 1.1446 & 0.352 & 17 \\
+8 & 0.3612 & 0.418 & 17 \\
+10 & 3.2521 & 2.529 & \\
\hline
\end{tabular}

*** Significant at the $1 \%$ level under a two-tailed test.

** Significant at the 5\% level under a two-tailed test.

* Significant at the $10 \%$ level under a two-tailed test.

\section{References}

1. Aharony, J., and I. Swary. "Contagion Effects of Bank Failures: Evidences From Capital Markets." Journal of Business, 56, 1983, pp. 305-322.

2. $\quad$ Bannister, J. W. "Earnings Signals and Inter-Firm Information Transfers." Journal of Business, Finance \& Accounting, 21, 1994, pp. 1127-1149.

3. Cheng, L. T. W., and J. E. McDonald. "Industry Structure and Ripple Effects of Bankruptcy Announcements." Financial Review, 31, 1996, pp. 783-807.

4. $\quad$ Chow, C. W., and S. J. Rice. "Qualified Audit Opinions and Share Prices An Investigation." Auditing: A Journal of Practice and Theory, 1, 1982, pp. 35-53.

5. Clinch, G. J., and N. A. Sinclair. "Intra-Industry Information Releases." Journal of Accounting and Economics, 9, 1987, pp. 89-106.

6. $\quad$ Cornell, B., and A. Shapiro. "The Reaction of Bank Stock Prices to the International Debt Crises." Journal of Banking and Finance, 10, 1986, pp. 55-73.

7. DeBondt, W., and R. Thaler. "Does the Stock Market Overreact?" Journal of Finance, 40, 1985, pp. 793805 .

8. _ _ "Further Evidence on Investor Overreaction and Stock Market Seasonality." Journal of Finance, 42, 1987, pp. 557-581.

9. $\quad$ Dodd, P., N. Dopuch, R. W. Holthausen, and R. W. Leftwich. "Qualified Audit Opinions and Stock Prices: Information Content, Announcement Dates and Concurrent Disclosures." Journal of Accounting and Economics, 6, 1984, pp. 3-38.

10. Dopuch, N., R. W. Holthausen, and R. W. Leftwich. "Abnormal Returns Associated With Media Disclosures of 'Subject to' Qualified Audit Opinions." Journal of Accounting and Economics, 8, 1986, pp. 93-117.

11. Elliott, J. "'Subject to' Audit Opinions and Abnormal Security Returns Outcomes and Ambiguities." Journal of Accounting Research, 20, 1982, pp. 617-638. 
12. Firth, M. "The Impact of Earnings Announcements on the Share Price Behavior of Similar Type Firms." Economic Journal, 86, 1976, pp. 296-306.

13. Foster, G. "Intra-Industry Information Transfers Associated With Earnings Releases." Journal of Accounting and Economics, 3, 1981, pp. 201-232.

14. Gay, G. D., S. G. Timme, and K. Yung. "Bank Failure and Contagion Effects: Evidence From Hong Kong." The Journal of Financial Research, 14, 1991, pp. 153-168.

15. Glied, Sherry, "Health Care Costs: On The Rise Again," Journal of Economic Perspectives, Vol. 17, No. 2, Spring 2003, pp. 125-148.

16. Howe, J. "Evidence on Stock Market Overreaction." Financial Analysts Journal, 42, 1986, pp. 74-77.

17. Jacklin, C. J., and S. Bhattacharya. "Distinguishing Panics and Information-Based Bank Runs: Welfare and Policy Implication." Journal of Political Economy, 96, 1988, pp. 568-580.

18. Jones, F. L. "The Information Content of the Auditor's Going Concern Evaluation." Journal of Accounting and Public Policy, 15, 1996, pp. 1-27.

19. Lang, L. H., and R. M. Stulz. "Contagion and Competitive Intra-Industry Effects of Bankruptcy Announcements: An Empirical Analysis." Journal of Financial Economics, 32, 1992, pp. 45-60.

20. Laux, Paul, Laura T. Starks, and Pyung Sig Yoon, "The Relative Importance of Competition and Contagion in Intra-industry Information Transfers: An Investigation of Dividend Announcements." Financial Management, Vol. 27, Issue 3, autumn 1998, pp. 5-16.

21. Smirlock, M., and H. Kaufold. "Bank Foreign Lending, Mandatory Disclosure Rules, and the Reaction of Bank Stock Prices to the Mexican Debt Crisis." Journal of Business, 60, 1987, pp. 347-364.

22. Sun, H. L., and Alex P. Tang, "The Intra-industry Information Effect of Downsizing Announcements." American Business Review, 16, June 1998, pp. 68-76. 